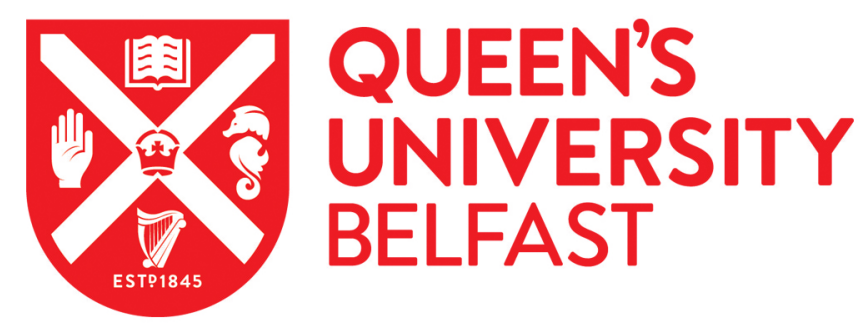

\title{
Testing the Prebish-Singer hypothesis using second-generation panel data stationarity tests with a break
}

Arezki, R., Hadri, K., Kurozumi, E., \& Rao, Y. (2012). Testing the Prebish-Singer hypothesis using secondgeneration panel data stationarity tests with a break. Economics Letters, 117(3), 814-816.

https://doi.org/10.1016/j.econlet.2012.08.035

\section{Published in: \\ Economics Letters}

\section{Document Version:}

Peer reviewed version

Queen's University Belfast - Research Portal:

Link to publication record in Queen's University Belfast Research Portal

\section{Publisher rights}

This is the author's version of a work that was accepted for publication in Economics Letters. Changes resulting from the publishing process, such as peer review, editing, corrections, structural formatting, and other quality control mechanisms may not be reflected in this document. Changes may have been made to this work since it was submitted for publication. A definitive version was subsequently published in Economics Letters, VOL 117, ISSUE 3, 12/2012

\section{General rights}

Copyright for the publications made accessible via the Queen's University Belfast Research Portal is retained by the author(s) and / or other copyright owners and it is a condition of accessing these publications that users recognise and abide by the legal requirements associated with these rights.

Take down policy

The Research Portal is Queen's institutional repository that provides access to Queen's research output. Every effort has been made to ensure that content in the Research Portal does not infringe any person's rights, or applicable UK laws. If you discover content in the Research Portal that you believe breaches copyright or violates any law, please contact openaccess@qub.ac.uk. 


\section{Accepted Manuscript}

Testing the Prebish Singer hypothesis using second generation panel

data stationarity tests with a break

Rabah Arezki, Kaddour Hadri, Eiji Kurozumi, Yao Rao

PII:

S0165-1765(12)00470-3

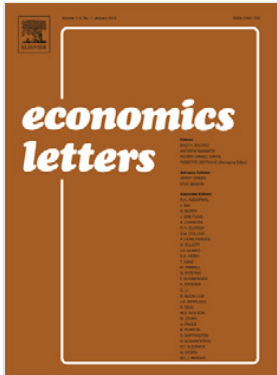

DOI:

10.1016/j.econlet.2012.08.035

Reference: $\quad$ ECOLET 5589

To appear in: Economics Letters

Received date: 30 April 2012

Revised date: 27 June 2012

Accepted date: 16 August 2012

Please cite this article as: Arezki, R., Hadri, K., Kurozumi, E., Rao, Y., Testing the Prebish Singer hypothesis using second generation panel data stationarity tests with a break.

Economics Letters (2012), doi:10.1016/j.econlet.2012.08.035

This is a PDF file of an unedited manuscript that has been accepted for publication. As a service to our customers we are providing this early version of the manuscript. The manuscript will undergo copyediting, typesetting, and review of the resulting proof before it is published in its final form. Please note that during the production process errors may be discovered which could affect the content, and all legal disclaimers that apply to the journal pertain. 
- We tested the PS hypothesis employing two recent panel stationary tests.

- We found that all the 9 commodities considered are mean reverting (stationary).

- All the 9 real commodity prices have a significant negative growth rate except oil.

- The 9 commodities are pairwise positively correlated except with the price of oil. 


\title{
Testing the Prebish Singer Hypothesis using Second Generation Panel Data Stationarity Tests with a break
}

\author{
Rabah Arezki \\ International Monetary Fund \\ Washington DC \\ Eiji Kurozumi ${ }^{2}$ \\ Department of Economics \\ Hitotsubashi University
}

\author{
Kaddour Hadri ${ }^{1}$ \\ Queen's University Management School \\ Queen's University Belfast \\ Yao Rao \\ Liverpool Management School \\ Liverpool University
}

\begin{abstract}
In this paper, we test the Prebish-Singer (PS) hypothesis which states that real commodity prices decline in the long run, using two recent powerful panel data stationarity tests accounting for cross sectional dependence and a structural break. We find that the hypothesis cannot be rejected for most commodities but oil.
\end{abstract}

JEL classification: C12, C33, N50, O13, Q32.

Key words: Panel data, stationarity tests, cross-sectional dependence, Prebish-Singer hypothesis, structural break.

\footnotetext{
${ }^{1}$ Corresponding author: Kaddour Hadri, 185 Stranmillis road, Queen's University Management School, Queen's University, Belfast, BT9 5EE, UK. Tel +44 (0)28 9097 5618. Fax +44 (0)28 9097 4201. Email: k.hadri@qub.ac.uk

${ }^{2}$ Hadri's and Kurozumi's research were supported by JSPS and BA under the Japan-Britain Research Cooperative Program.
} 


\section{Introduction}

This paper investigates the empirical validity of the so-called Prebish-Singer (PS) hypothesis. We recall that the PS hypothesis (see Hadri 2011 for more references) states that real commodity prices follow a downward secular trend. Prebish (1950) and Singer (1950) claimed that there had been a downward long-term trend in these prices and that this decline in these prices is likely to carry on. The consequences of this hypothesis are very important for developing countries because many of them depend on only few primary commodities to generate most of their export earnings. This overwhelming reliance on commodities has serious policy consequences. In case of actual long-run downward trend of the exported commodities, the concerned country might have to explore diversification of its export portfolio to include manufactures and services.

\section{Literature review}

The first empirical studies revealing a downward real price assumed that $y_{t}$, the real commodity price, is generated by a stationary process around a time trend $(I(0))$ :

$$
y_{t}=\beta_{0}+\beta_{1} t+\varepsilon_{t}, t=1, \ldots, T,
$$

where $t$ is a linear trend and the random variable $\varepsilon_{t}$ is stationary with mean 0 and

variance $\sigma_{\varepsilon}^{2}$. The parameter of interest is the slope $\beta_{1}$, which is predicted negative under the PS hypothesis. Grilli and Yang (1988), inter alia, employing a data set of 24 annual commodity prices found that a weighted aggregate index dropped by $0.6 \%$ per annum. Other researchers assumed that commodity prices were generated by a so called differencestationary (DS or $I(1))$ model, implying that $y_{t}$ is non-stationary:

$$
\Delta y_{t}=\beta_{1}+v_{t}, t=1, \ldots, T
$$

where $v_{t}$ is stationary and invertible. Some empirical studies employing equation (2) 
show evidence against the PS hypothesis. In particular, Kim et al. ( 2003) found that relative commodity prices behave like unit root processes (nonstationary process) and only five commodity prices amongst the 25 commodity prices included in the Grilli-Wang index exhibit the negative trend predicted by the PS hypothesis. It is well known, now, that if $y_{t}$ is a DS process, then using equation (1) to test the null hypothesis: $\beta_{1}=0$ will result in acute size distortions, leading to a wrong rejection of the null when no trend is present, even asymptotically. Alternatively, if the true generating process is given by equation (1) and we base our test on equation (2). Our test becomes inefficient and less powerful than the one based on the correct equation. Therefore, when testing the PS hypothesis we have first to test the order of integration of our relative commodity prices in order to use the right equation. The problem might be compounded by the presence of structural breaks in equation(1) or (2). In this case, the true generating process may be a trend stationary process with breaks:

$$
y_{t}=\beta_{0}+\beta_{1} t+\delta D U_{t}\left(\omega^{*}\right)+\gamma D T_{t}\left(\omega^{*}\right)+\varepsilon_{t}, t=1, \ldots, T,
$$

or, alternatively, a difference stationary with breaks:

$$
\Delta y_{t}=\beta_{1}+\delta D_{t}\left(\omega^{*}\right)+\gamma D U_{t}\left(\omega^{*}\right)+\Delta \varepsilon_{t}, t=2, \ldots, T,
$$

where $D T_{t}\left(\omega^{*}\right)=t-T^{*}$ when $t>T^{*}$ and 0 otherwise, $D U_{t}\left(\omega^{*}\right)=1$ if $t>T^{*}$ and 0 otherwise, and $D_{t}\left(\omega^{*}\right)=1$ when $t=T^{*}+1$ and 0 otherwise, with $T^{*}=\left[\omega^{*} T\right]$ the break date with the associated break fraction $\omega^{*} \in(0,1)$ and [.] denotes the integer part of the argument. As shown by Perron (1989), the properties of tests for the presence of a break in trend are also highly dependent on the order of integration of the series concerned.

To increase the power of these tests we may use panel unit-root and/or stationarity tests which are well known to be more powerful than their single time series counter-part. The knowledge that commodity prices are stationary (mean reverting) or non-stationary is crucial for the design of economic policy. In the case where commodity prices are mean 
reverting any shock will have only a transitory effect. Whereas if commodity prices are nonstationarity, shocks imprint a permanent effect on those prices.

\section{Data and results}

\subsection{Data}

The annual data set used covers the period 1960-2007. We employed 9 primary commodity prices relative to the US CPI index (zinc, tin, oil, wool, iron, aluminium, beef coffee and cocoa). The summary statistics and graphs of our data can be provided by the authors on request.

\subsection{Testing whether the series are mean reverting using panel data sta- tionarity tests}

It is well known that univariate time series tests for unit root and stationarity have very low power. It has been shown through simulations that panel data tests for unit root and stationarity are far more powerful than their univariate counterpart (see Baltagi (2008) for a review of this literature). In this paper, we shall use two recent panel stationarity tests proposed by Hadri and Rao (2008) and Hadri and Kurozumi (2012) respectively. The later has been extended here to allow for a break in the intercept or the trend or in both like in Hadri and Rao (2008). Since the pioneering work of Perron (1989) which illustrates the need to allow for a structural break when testing for a unit root in economic time series, the problem of structural breaks in the level/slope of a series has proved to be of considerable interest in the unit root testing literature. Perron (1989) has found that unit root tests are biased toward accepting the false unit root null hypothesis in the presence of a structural break. It is widely accepted that the failure of taking into account structural breaks is likely to lead to a significant loss of power in unit root tests. Similarly, stationarity tests ignoring the existence of breaks diverge and thus are biased toward rejecting the null hypothesis of stationarity in favour of the false alternative of a unit root hypothesis. This is due to 
severe size distortion caused by the presence of breaks (see inter alia Lee et al. (1997)). Kurozumi (2002), Lee and Strazicich (2001) and Busetti and Harvey (2001, 2003) have considered testing the null hypothesis of stationarity in the presence of a single break versus the alternative of a unit root in time series. The selection of the appropriate break model for each price series, amongst the four possible ones, is data driven. Any serial correlation is mopped out. It also correct for the very likely presence of cross-sectional dependence for the first test via the bootstrapping method and for the second test, using the method proposed in Pesaran (2007) to mop-up the effect of a cross-sectional dependence in the form of a common factor in the disturbance. It has been shown by, inter alia, O'Connell (1998) and Strauss and Yigit (2003) that the size of the test in the presence of unaccounted cross sectional correlation is considerably distorted. We calculated the pairwise correlation coefficients across prices (these coefficients may be provided by the authors upon request). There are positive and significant between real commodity prices except with oil price series where the coefficients are relatively small some negative but all insignificant (at $5 \%$ significance level). Pindyck and Rotemberg (1990) noted this strong correlation in the prices of unrelated commodities which they called "Excess co-movement". They found that even after controlling for current and expected future values of macroeconomic variables this excess co-movement remains.

By using panel we are able to account for this cross sectional dependence. We are in a position to test jointly the null hypothesis that all the commodity prices are stationary $(I(0))$ against the alternative that some of them are nonstationary or unit root processes $(I(1))$. The results of the first test are given in Table 1.

Table 1. Panel Stationary test Results (Hadri and Rao (2008))

\begin{tabular}{llllll}
\hline \hline & $N$ & $T$ & statistic value & \multicolumn{2}{l}{ Bootstrap critical values } \\
\hline & & & & $10 \%$ & $5 \%$ \\
\hline Using tsig criterion & 9 & 48 & 3.913 & 11.164 & 12.617 \\
Using BIC criterion & 9 & 48 & 2.647 & 7.824 & 8.975 \\
\hline \hline
\end{tabular}

The null hypothesis that all the commodity prices are stationary is not rejected indicating that all the commodity prices are mean reverting (the two criteria used are for the correction 
for possible serial correlation, see Hadri and Rao (2008) for more explanations). This is an important result. It means that shocks have only temporary effect on real commodity prices. The fact that the 9 commodity prices are stationary will permit us to use classical econometrics tools to test the PB hypothesis. The latter test is given in Table 2.

\subsection{Testing whether the series have downward trends}

All commodities without a break have a significant negative trend except oil which is positive but not significant, as shown in Table 2 . The ones with a break have a significant negative trend before the break and a positive but insignificant trend after the break. The estimations after the break are not reliable because of the size of the sample (only 5 observations).

\begin{tabular}{|c|c|c|c|}
\hline & $\begin{array}{c}\text { Growth Rate }(\%) \\
\text { (no break) }\end{array}$ & before break & after break. \\
\hline Zinc & & $\begin{array}{c}-0.0087 \\
(.0055)\end{array}$ & $\begin{array}{c}0.35078 \\
(0.993)\end{array}$ \\
\hline Tin & & $\begin{array}{c}-0.033 \\
(0.000)\end{array}$ & $\begin{array}{c}0.1905 \\
(0.97)\end{array}$ \\
\hline Oil & $\begin{array}{c}0.0214 \\
(1)\end{array}$ & & \\
\hline Wool & $\begin{array}{c}-0.0205 \\
(0.000)\end{array}$ & & \\
\hline Iron & & $\begin{array}{c}-0.0184 \\
(0.000)\end{array}$ & $\begin{array}{c}0.2339 \\
(0.994)\end{array}$ \\
\hline Aluminium & $\frac{-0.16}{(0.000)}$ & & \\
\hline Beef & $\begin{array}{c}-0.024 \\
(0.000)\end{array}$ & & \\
\hline Coffee & $\begin{array}{c}-0.294 \\
(0.000)\end{array}$ & & \\
\hline Cocoa & $\begin{array}{c}-0.0254 \\
(0.000)\end{array}$ & & \\
\hline
\end{tabular}

The result of the tests employing Hadri and Kurozumi (2012), recently published in this journal, accounting for cross section dependence à la Pesaran and extended to allow for a structural break are given in Table 3 .

Table 3. Hadri Kurozumi (2012) Panel Stationary test extended to account for a structural break 


\begin{tabular}{lccc}
\hline \hline & $N$ & $T$ & statistic value $^{3}$ \\
\hline Using Sul, Phillips and Choi (2005) long run variance estimator & 9 & 48 & -2.0497 \\
\hline
\end{tabular}

The null hypothesis that all the commodity prices are stationary is again not rejected in Table 3, at all the usual levels of significance, indicating that all the commodity prices are stationary. This is reinforcing the previous result. It means that shocks have only temporary effects on real commodity prices although, these effects might be very persistent as shown, inter alia, by Cuddington and Jerret (2008). We also obtain the same results as the ones reported in Table 2 with all real commodity prices having a significant negative growth except oil which is positive but insignificant.

\section{Conclusion}

We tested the PS hypothesis employing two recent panel stationary tests, accounting for cross sectional dependence and a structural break, to test for the stationarity of 9 real commodity prices and found that in both tests, the hypothesis is true for the 9 real commodity prices.

We found that all the 9 commodities included in our sample are mean reverting (stationary) via panel stationary test. All the 9 real commodity prices have a significant negative growth rate except oil which is positive but not significant. We also discovered that the 9 commodities are pairwise positively and significantly correlated except with the real price of oil. The correlations between oil and the rest are not significantly correlated.

\footnotetext{
${ }^{3}$ Reject null hypothesis when the statistic is greater than 1.645
} 


\section{References}

[1] Baltagi, B. H. (2008). Econometric Analysis of Panel Data . Chichester, Wiley.

[2] Busetti, F. and Harvey, A. C. (2003). Further comments on stationarity tests in series with structural breaks at unknown points. Journal of Time Series Analysis 24, 137-140.

[3] Chang, Y. (2004). Bootstrap unit root tests in panels with cross-sectional dependency. Journal of Econometrics 110, 261-292.

[4] Cuddington, J., and D. Jerret (2008). Super Cycles in Metal Prices?, IMF staff Papers, $55(4), 541-565$.

[5] Hadri, K. (2000). Testing for stationarity in heterogeneous panel data. Econometrics Journal 3, 148-161.

[6] Hadri K. (2011) "Primary Commodity Price Series: Lessons for Policymakers in Ressource-Rich Countries", in Beyond the Curse: Policies to Harness the Power of Natural Resources, R. Arezki, T. Gylfason \& A. Sy, eds. (IMF, 2011)

[7] Grilli, R.E., and M.C. Yang (1988). Commodity Prices, Manufactured goods Prices, and the terms of trade of Developing Countries. World Bank Economic Review, 2, $1-48$.

[8] Hadri K. (2011) "Primary Commodity Price Series: Lessons for Policymakers in Ressource-Rich Countries", in Beyond the Curse: Policies to Harness the Power of Natural Resources, R.Arezki, T.Gylfason \& A.Sy, eds. (IMF, 2011). Invited address, High Level Seminar, IMF Institute \& Central Bank of Algeria, Algiers 2010. Chap. 7, $119-130$

[9] Hadri, K. and Y. Rao, (2008) Panel stationarity test with breaks. Oxford Bulletin of Economics and Statistics, 70(2), 245-269. 
[10] Hadri, K. and Eiji Kurozumi (2011). A Locally Optimal Test for No Unit Root in Cross-Sectionally Dependent Panel Data. Hitotsubashi Journal of Economics, Vol.52, No.2, pp.165-184.

[11] Hadri K., and Eiji Kurozumi (2012) "A Simple Panel Stationarity Test in the Presence of serial correlation and a common factor", Economics Letters,.Vol. 115, pp. 31-34.

[12] Lee, J., C. J. Huang and Y. Shin (1997). On stationary tests in the presence of structural breaks. Economics Letters 55, 165-172.

[13] Lee, J. and M. Strazicich (2001). Testing the null of stationarity in the presence of a structural break. Applied Economics Letters 8, 377-382.

[14] Lewis, A. (1954). Economic Development with Unlimited Supplies of Labour, Manchester School of Economics and Social Studies, 22, 139-191.

[15] Kapetanios G., M.H. Pesaran, T. Yamagata (2011), Panels with Nonstationary Multifactor Error Structures, Journal of Econometrics 160, 326-348.

[16] Kim, T., Pfaffenzeller, S., Rayner, A., Newbold, P. (2003). Testing for linear trend with application to relative primary commodity prices. Journal of Time Series Analysis, 24, 539-551.

[17] Kurozumi, E. (2002). Testing for stationarity with a break. Journal of Econometrics 108, 63-69.

[18] O'Connell, P. (1998). The overvaluation of purchasing power parity. Journal of International Economics 44, 1-19.

[19] Perron, P., (1989). The Great Crash, the Oil Price Shock, and the Unit Root Hypothesis. Econometrics, 57, 1361-1401.

[20] Pesaran, M. H. (2007). A simple panel unit root test in the presence of cross-section dependence. Journal of Applied Econometrics 22, 265-312. 
[21] Pindyck, R.S., and J.J. Rotember (1990). The Excess Co-Movements of Commodity Prices. The Economic Journal, 100, 1173-1189.

[22] Prebish, R., (1950). The Economic Development of Latin America and Its Principal Problems. Economic Bulletin for Latin America, 7, 1-12.

[23] Singer, H., (1950). The Distribution of Gains between Investing and Borrowing Countries, American Economic review, Papers and Proceedings, 40, 473-485.

[24] Sul, D., P. C. B. Phillips and C. Y. Choi (2005). Prewhitening bias in HAC estimation. Oxford Bulletin of Economics and Statistics, 67, 517-546.

[25] Strauss, J. and T. Yigit (2003). Shortfalls of panel unit root testing. Economics Letters 81, 309-313.

[26] Tzavalis, E. (2002). Structural breaks and unit roots in short panels, mimeo, University of London. 